Abstract AB0814 - Table 1. Descriptive data of 7 patients treated with STS

\begin{tabular}{|c|c|c|c|c|c|c|c|c|c|}
\hline Diagnosis & $\begin{array}{l}\text { Age/ } \\
\text { gender }\end{array}$ & Localization & $\begin{array}{l}\text { Number of } \\
\text { injections }\end{array}$ & $\begin{array}{l}\text { Interval } \\
\text { (days) }\end{array}$ & $\begin{array}{l}\text { Dosis } \\
(\mathrm{mg})\end{array}$ & $\begin{array}{l}\text { VAS pre- } \\
\text { treatment } \\
\quad(\mathrm{mm})\end{array}$ & $\begin{array}{l}\text { VAS after treament } \\
(\mathrm{mm})\end{array}$ & $\begin{array}{c}\text { Size pre } \\
\text { treatment } \\
(\mathrm{mm})\end{array}$ & $\begin{array}{l}\text { Size after treatment } \\
(\mathrm{mm})\end{array}$ \\
\hline \multirow[t]{2}{*}{$\mathrm{DM}$} & $33, \mathrm{~F}$ & Left leg (medial) & 3 & 15 & 2 & 10 & 0 & 1.1 & 1.1 \\
\hline & & Left leg (posterior) & 3 & & 2 & & & 0.8 & 0.6 \\
\hline \multirow[t]{2}{*}{$\begin{array}{l}\text { Limited } \\
\text { SSc }\end{array}$} & $67, F$ & $\begin{array}{l}\text { Hand dystal } \\
\text { phalanx }\end{array}$ & 2 & 15 & 5 & 80 & 60 & 1.6 & 1.4 \\
\hline & & Elbow & 2 & & 12 & & & 1.2 & 1.2 \\
\hline Limited & $55, F$ & Elbow & 3 & 15 & 10 & 0 & 0 & 2.5 & 2.5 \\
\hline SSc & & Leg & 3 & & 20 & & & 2.3 & 2.3 \\
\hline $\begin{array}{l}\text { Limited } \\
\text { SSc }\end{array}$ & $67, \mathrm{~F}$ & $\begin{array}{l}\text { Hand dystal } \\
\text { phalanx }\end{array}$ & 8 & 15 & 9.1 & 50 & 20 & 1.6 & 1.7 \\
\hline $\begin{array}{l}\text { Diffuse } \\
\text { SSc }\end{array}$ & $52, F$ & Ear & 2 & 23 & 7.6 & 70 & 20 & 0.5 & 0.5 \\
\hline $\begin{array}{l}\text { Diffuse } \\
\text { SSc }\end{array}$ & $56, F$ & $\begin{array}{l}\text { Hand dystal } \\
\text { phalanx }\end{array}$ & 4 & 12 & 7.5 & 60 & 60 & 2.5 & 2.3 \\
\hline $\begin{array}{l}\text { Diffuse } \\
\text { SSc }\end{array}$ & $62, \mathrm{M}$ & Elbow & 3 & 30 & 17.5 & 0 & 0 & 13. & 13.21 \\
\hline Mean $\pm S d$ & $56 \pm 10.14$ & - & $3.3 \pm 1.67$ & $17.85 \pm 5.86$ & $9.27 \pm 5.66$ & $38,75 \pm 31.81$ & $22,85 \pm 24.90$ & $2.73 \pm 3.55$ & $2.70 \pm 3.62$ \\
\hline
\end{tabular}

${ }^{*} \mathrm{DM}=$ dermatomyositis and $\mathrm{SSc}=$ systemic sclerosis; $\mathrm{Sd}=$ standart deviation

\section{AB0815 HEALTH RELATED QUALITY OF LIFE IN PATIENTS WITH SYSTEMIC SCLEROSIS TREATED WITH TWO DIFFERENT INTRAVENOUS ILOPROST REGIMENS}

T. Schioppo $^{1}$, L. Scalone ${ }^{2,3}$, P. Cozzolino ${ }^{2}$, L. Mantovani ${ }^{2,3}$, G. Cesana ${ }^{2}$, O. De Lucia $^{1}$, A. Murgo ${ }^{1}$, F. Ingegnoli $1,4 .{ }^{1}$ Rheumatology, Pini, Milan; ${ }^{2}$ CESP, University of Milan Bicocca, Monza; ${ }^{3}$ Fondazione CHARTA; ${ }^{4}$ University of Milan, Milan, Italy

Background: In systemic sclerosis (SSc), Raynaud's phenomenon (RP) and dig ital ulcers (DU) can decrease health related quality of life (HRQoL). Intravenous (IV) iloprost (ILO) is administered for RP, after oral therapy failure, and DU healing. HRQoL is considered fundamental to assess the impact of the disease and therapy on patients: EQ-5D-5L has been satisfactory used to assess the genera HRQoL in SSc.

Objectives: Aim of our study was to estimate HRQoL in SSc patients treated with two different IV ILO regimens and in patients not requiring IV ILO.

Methods: This was a monocentric, prospective, pragmatic and non-randomised study. Enrolled SSc patients were divided into 3 groups: no IV ILO (group A), IV ILO once monthly (B) or IV ILO for 5 consecutive days every 3 months (C). HRQoL was assessed using EQ-5D-5L through a telephone interview. Group A patients were evaluated at baseline and after 3 months; group B 2 days before each infusion and 2 weeks after each infusion; group $C 2$ days before each therapy cycle, and after 2 and 6 weeks after the first cycle of therapy. The EQ-5D-5L describes HRQoL, measures the overall health state with a $0-100$ visual analogue scale (VAS) and values health with a utility index. Multiple regression analyses was performed to calculate VAS and mean utility index in each group (confounders: age, sex, treatment group, baseline utility or VAS score, average outdoor temperature the week before the evaluation at patient's place of residence, RP VAS, disease duration and modified Rodnan skin score).

Results: 96 patients were enrolled: 52 in group A, 24 in B, and 20 in C. Of these 35,21 and 16 completed the study respectively. Utility and VAS score at the end of the three months, as adjusted for the possible confounders, were not statistically different in the three groups.

Conclusions: Utility and VAS, at 3 months follow-up, were not different in the 3 groups as if IV ILO was able to make patients requiring IV ILO as similar as patients not requiring IV ILO. Moreover, in this model there was no difference between the two ILO regimens (1 days monthly vs 5 every 3 months). These results suggest that our therapeutic approach, based on various criteria such as demographic, clinical characteristics, logistic aspects and patients' preferences, allows to reach or to maintain HRQoL at comparable levels between the three groups considered.

Acknowledgements: Meteo Operations Italia SrL - Centro Epson Meteo for temperature data.

Disclosure of Interest: None declared

DOI: 10.1136/annrheumdis-2018-eular.2061

\section{AB0817 1 PROMINENT NAILFOLD CAPILLARY AVASCULAR AREA PREDICTS MALIGNANCY IN PROGRESSIVE SYSTEMIC SCLEROSIS}

W.-N. Huang ${ }^{1,2}$, Y.-M. Chen ${ }^{1,2,3}$, W.-T. Hung ${ }^{1}$, C.-W. Hsieh ${ }^{1}$, C.-T. Lin ${ }^{1}$, Y.$\mathrm{H}$. Chen ${ }^{1,2} .{ }^{1}$ Allergy, Immuology And Rheumatology, Taichung Veterans General Hospital, Taichung: ${ }^{2}$ Faculty of Medicine, National Yang Ming University, Taipei;

${ }^{3}$ Institute of Biomedical Science, National Chung Hsing University, Taichung, Taiwan, Province of China

Background: Systemic sclerosis (SSc) is an autoimmune disease characterised with proximal scleroderma and internal organ involvement. Observational studies demonstrated increased incidences of cancer in SSc patients ${ }^{1}$. Nailfold capillaroscopy is useful for the diagnosis and disease activity assessment of SSc.

Abstract AB0815 - Table 1

\begin{tabular}{|c|c|c|c|c|c|c|c|c|}
\hline \multirow{3}{*}{$\begin{array}{l}\text { Independent } \\
\text { variable description } \\
\text { Age (years) }\end{array}$} & \multicolumn{4}{|c|}{ Utility } & \multicolumn{4}{|c|}{ VAS } \\
\hline & \multirow{2}{*}{$\begin{array}{c}\text { Coefficient } \\
-0,001\end{array}$} & \multirow{2}{*}{$\begin{array}{c}\mathrm{P} \\
0149\end{array}$} & \multicolumn{2}{|c|}{$95 \% \mathrm{Cl}$} & \multirow{2}{*}{$\begin{array}{c}\text { Coefficient } \\
-0,332\end{array}$} & \multirow{2}{*}{$\begin{array}{c}\mathrm{P} \\
0026\end{array}$} & \multicolumn{2}{|c|}{$95 \% \mathrm{Cl}$} \\
\hline & & & $-0,002$ & 0000 & & & $-0,623$ & $-0,041$ \\
\hline \multicolumn{9}{|l|}{ Sex } \\
\hline Female (reference) & - & - & - & - & - & - & - & - \\
\hline Male & 0028 & 0148 & $-0,010$ & 0067 & 3637 & 0521 & $-7,618$ & 14891 \\
\hline \multicolumn{9}{|l|}{ Treatment group } \\
\hline $\begin{array}{l}\text { ILO monthly } \\
\text { (reference) }\end{array}$ & - & - & - & - & - & - & - & - \\
\hline $\begin{array}{l}\text { ILO for } 5 \text { days } \\
\text { every } 3 \text { months }\end{array}$ & 0001 & 0975 & $-0,037$ & 0038 & 7252 & 0182 & $-3,486$ & 17990 \\
\hline No ILO & $-0,005$ & 0771 & $-0,037$ & 0028 & 9160 & 0005 & $-0,185$ & 18505 \\
\hline Utility at baseline & 0731 & 0000 & 0526 & 0936 & 0270 & 0012 & 0061 & 0478 \\
\hline $\begin{array}{l}\text { Average } \\
\text { temperature }\end{array}$ & 0003 & 0155 & $-0,001$ & 0007 & 0219 & 0714 & $-0,971$ & 1409 \\
\hline RP VAS & $-0,005$ & 0054 & $-0,010$ & 0000 & $-1,114$ & 0131 & $-2,569$ & 0341 \\
\hline Disease duration & 0001 & 0534 & $-0,001$ & 0002 & 0172 & 0510 & $-0,348$ & 0693 \\
\hline Skin score (mRSS) & $-0,003$ & 0021 & $-0,006$ & $-0,001$ & $-0,161$ & 0695 & $-0,977$ & 0655 \\
\hline Constant & 0241 & 0025 & 0032 & 0451 & 68969 & 0000 & 37504 & 100,43 \\
\hline
\end{tabular}


However, whether the nailfold capillaroscopy pattern is distinct in SSc patients with malignancy remained unknown.

Objectives: The aim of this study was to investigate the incidence rate of malignancy in SSc patients. Nailfold capillaroscopy morphology patterns in SSc patients with cancer were also compared to those without cancer.

Methods: During 2004 to 2014 , consecutive 310 SSc patients who visited outpatient clinics at Taichung Veterans General Hospital, Taiwan were enrolled. Nailfold capillaroscopy was performed at a magnification of 200x. Abnormal morphology description were analysed and categorised by the scoring system proposed by Dr. Cutolo ${ }^{2}$. SSc with malignancy was defined if the subject had a cancer diagnosis during the follow-up period.

Results: Among 310 SSc patients, 28 (10.9\%, 13 males, 25 females) patients had cancer. The mean age of SSc with malignancy is $62 \pm 10.9$ years. Sixty-four percent SSc patients with cancer is diffuse type, but only $42 \%$ of them were tested positive for anti-Scl-70 antibodies. The most common cancer were genitourinary tract and gastrointestinal tract, accounting for almost two-thirds patients. Cancer and SSc were frequently diagnosed at the same year. In SSc patients with cancer, 19 patients received nailfold capillary microscope exams when SSc was diagnosed. The assessment of nailfold capillaroscopy morphology patterns in SSc patients with cancer demonstrated neither enlarged loop, giant loop, microhemorrhage nor angiogenesis. However, prominent avascular areas could be observed universally in SSc patients with malignancy.

Conclusions: Rheumatologists should be aware of malignancy in SSc patients, especially those with diffuse type and within the 1st year of symptoms onset. SSc patients with malignancy tend to present atypical capillaroscopic pattern of prominent avascular area without loop dilatation, microhemorrhage and angiogenesis.

\section{REFERENCES:}

11] Bonifazi M, et al.,Rheumatology (Oxford). 2013 Jan;52(1):143-54

[2] Maurizio Cutolo (2010) Atlas of Capillaroscopy in Rheumatic diseases chapter 11 page $77-86$

Disclosure of Interest: None declared

DOI: 10.1136/annrheumdis-2018-eular.6517

\section{AB0818 THE COMPARATIVE STUDY OF SYSTEMIC SCLEROSIS AND SYSTEMIC LUPUS ERYTHEMATOSUS- ASSOCIATED PULMONARY ARTERIAL HYPERTENSION}

Y. Feng, J. Wang, Y. Lei, X. Zhang. Department of Rheumatology, Guangdong Academy of Medical Sciences/Guangdong General Hospital, Guangzhou, China

Background: Systemic Sclerosis(SSc) is the main cause of Connective Tissue Disease-associated pulmonary arterial hypertension (CTD-PAH) in western countries, while Systemic Lupus Erythematosus(SLE) is the first cause in Asian. Systemic Sclerosis(SSc) is the main cause of Connective Tissue Disease-associated pulmonary arterial hypertension (CTD-PAH) in western countries, while Systemic Lupus Erythematosus(SLE) is the first cause in Asian.

Objectives: This study aimed to identify the clinical difference between SSc-PAH and SLE-PAH.

This study aimed to identify the clinical difference between SSc-PAH and SLE$\mathrm{PAH}$.

Methods: SSc and SLE patients with pulmonary arterial hypertension who visited Guangdong General Hospital in China from 2009 to 2017 were recruited. PAH was diagnosed by transthoracic echocardiography or right heart catheterization and clinical data of patients was collected. Comparative study between SSc-PAH and SLE-PAH was conducted to identify the difference.

SSc and SLE patients with pulmonary arterial hypertension who visited Guangdong General Hospital in China from 2009 to 2017 were recruited. PAH was diagnosed by transthoracic echocardiography or right heart catheterization and clinical data of patients was collected. Comparative study between SSc-PAH and SLE-PAH was conducted to identify the difference.

Results: Twenty-nine SSc-PAH and 55 SLE-PAH patients were enrolled. The baseline characteristics of two groups was shown in table 1. In comparative study: the gender $(p=0.018)$, the age of PAH diagnosis $(p=0.001)$, Raynaud's phenomenon $(p<0.001)$, WHO function state $(p=0.019)$, PASP $(p=0.013)$, the diameter of $R A(p=0.045)$ and $R V(p=0.029)$ showed significant difference between SSc and SLE-PAH.
Abstract AB0818 - Table 1. Baseline Characteristics of SSc-PAH and SLE-PAH Patients

\begin{tabular}{|c|c|c|c|}
\hline $\begin{array}{l}\text { Female } \\
\text { Age }\end{array}$ & $\begin{array}{l}\text { SSc-PAH(29) } \\
23(79.3 \%) \\
46.0 \pm 14.3\end{array}$ & $\begin{array}{l}\text { SLE-PAH(55) } \\
53(96.4 \%) \\
34.2 \pm 10.3\end{array}$ & $\begin{array}{l}p \\
0.018 \\
0.001 \\
\end{array}$ \\
\hline Course'(year) & $3.0[0.5,6.4]$ & $0.8[0.0,9.5]$ & 0.833 \\
\hline Raynaud's phenomenon & $28(96.6 \%)$ & $22(40.0 \%)$ & $<0.001$ \\
\hline Anti-UIRNP antibody & $11(37.9 \%)$ & $27(49.1 \%)$ & 0.329 \\
\hline WHO Fc(III/TV) & $18(62.1 \%)$ & $45(84.9 \%)$ & 0.019 \\
\hline $\begin{array}{l}\text { NT-proBNP(pg/ml) } \\
\text { TTE }\end{array}$ & $2051[489,5227]$ & $1392[113,3632]$ & 0.176 \\
\hline PASP(mmHg) & $67.1 \pm 25.9$ & $81.1 \pm 24.0$ & 0.013 \\
\hline Diameter of RA(mm) & $48.9 \pm 7.7$ & $53.0 \pm 8.5$ & 0.045 \\
\hline Diameter of RV(mm) & $52.9 \pm 6.6$ & $55.9 \pm 6.7$ & 0.029 \\
\hline LVEF(\%) & $63.0 \pm 10.5$ & $67.4 \pm 7.6$ & 0.081 \\
\hline $\begin{array}{l}\text { Pericardial effusion } \\
\text { RHC }^{\boldsymbol{b}}\end{array}$ & $11(37.9 \%)$ & $22(41.5)$ & 0.752 \\
\hline SPAP(mmHg) & $88.3 \pm 17.5$ & $75.9 \pm 22.2$ & 0.109 \\
\hline DPAP(mmHg) & $28.0 \pm 9.2$ & $29.5 \pm 11.6$ & 0.764 \\
\hline mPAP(mmHg) & $48.3 \pm 11.7$ & $47.5 \pm 14.8$ & 0.773 \\
\hline PVR(WU) & $13.1 \pm 7.2$ & $11.4 \pm 6.1$ & 0.363 \\
\hline $\mathrm{Cl}\left(\mathrm{L} /\left(\min ^{*} \mathrm{~m}^{2}\right)\right)$ & $2.9 \pm 0.8$ & $3.2 \pm 1.1$ & 0.687 \\
\hline
\end{tabular}

TTE: transthoracic echocardiography; PASP: pulmonary arterial systolic pressure; RA: right atrium; RV: right ventricle; LVEF: left ventricle ejection fraction $\mathrm{RHC}$ : right heart catheterization; PAP: pulmonary arterial pressure; PVR: pulmonary vascular resistance; $\mathrm{Cl}$ : cardiac index.

a the time between the onset of CTD and PAH

${ }^{\mathrm{b}} 6 \mathrm{SSc}$ patients and all SLE patients received $\mathrm{RHC}$;

$\mathrm{n}=$ number at risk, $\mathrm{SpA}=$ Spondyloarthritis; $\mathrm{PsA}=\mathrm{Psoriatic}$ arthritis

Conclusions: The SSc-PAH patients tent to be older, have more angiopathic characteristics and more silent clinical course than SLE patients, which might bring some insight into the different pathophysiological process between SSc and SLE-PAH.

The SSc-PAH patients tent to be older, have more angiopathic characteristics and more silent clinical course than SLE patients, which might bring some insight into the different pathophysiological process between SSc and SLE-PAH.

Disclosure of Interest: None declared

DOI: 10.1136/annrheumdis-2018-eular.6906

\section{$\mathrm{AB} 0819$ \\ TFH CELLS CONTRIBUTE TO ABNORMAL B CELL PROFILES IN DERMATOMYOSITIS}

X. Zhang, X. Ma, H. Wang, Z. Chen, L. Sun. Department of Rheumatology And Immunology, THE AFFILIATED DRUM TOWER HOSPITAL, NANJING UNIVERSITY MEDICAL SCHOOL, NANJING, CHINA., Nanjing, China

Background: CD4 +CXCR5+PD-1+T follicular helper (Tfh) cells assist $B$ cells in their proliferation, differentiation and antibody class switch $\left({ }^{1}\right.$ Several studies indicate that Tfh cells play important roles in autoimmune diseases such as SLE, RA and pSS, which are characterised by the production of multiple antibodies $\left({ }^{2-4}\right.$ The frequency of Th cells in the peripheral blood from patients with dermatomyositis(DM) and whether they participate in the development of DM remain to be elucidated.

Objectives: To investigate the frequencies of Tfh cells and B cell profiles in DM patients. To further determine the association of Tfh cells and B cells in DM patients and clarify the possible mechanism.

Methods: Peripheral blood mononuclear cells (PBMCs) were isolated from DM patients and age, gender-matched healthy controls (HCs), respectively. The frequency of Tfh (CD4 +CXCR5+PD-1+) cells, total B (CD19+) cells naïve B (CD19 +CD27-) cells, memory B(CD19 +CD27+) cells and plasmablasts (CD19+CD38+ +) were examined by flow cytometry. The serum levels of IL-21, $\lg G, \lg M$, IgE and $\operatorname{IgA}$ were tested by enzyme linked immunosorbent assay (ELISA). 